\title{
Economic development versus conservation - a case study in a South African coastal area
}

\author{
C. J. Visser \& N. E. Bisset \\ Department of Water Affairs and Forestry, South Africa
}

\begin{abstract}
South Africa is a developing country with scarce water resources. Water is needed for economic development while the protection of the environment is of critical importance. As a result of historical imbalances, the access to industrial and agricultural water was in the past to a large extent controlled by a small percentage of the population in the country.

After 1998 the principles of allocation and use of water changed dramatically. Equitable access to the benefits of water resources, the sustainable use of water and the protection of water resources, became the main criteria.

With the assessment of applications for water use authorisations, the water authority must evaluate the relative importance of economic development and conservation. In a country with high levels of unemployment the protection of the environment cannot be at the expense of all development, but at levels that are sustainable in the long term.

Plettenberg Bay is a rapidly developing coastal holiday resort with big differences in income between socio-economic groups. There is also resistance to new developments in some circles. This town applied for authorisation to increase their abstraction of water from the Keurbooms River, which is the main source of water while it also flows through an ecologically sensitive estuary.

This paper explains the principles applicable to the authorisation procedure and it also presents a case study that shows the practical steps that were taken to accommodate different interest groups while trying to strike a balance between conservation and development.
\end{abstract}

Keywords: arid country, historical imbalances, redress, equitable access, sustainability, resource protection, beneficial use, public interest. 


\section{Introduction}

Although South Africa (SA) is seen as an economic leader in Africa, it is still internationally rated as a relatively poor country $(121 \mathrm{st}$ in the latest Human Development Index). By UN classification SA is a middle-income country with ample resources and by far the most developed country in Africa. However, more than $43 \%$ of the population remains under the poverty line, which is assessed as R3000,00 (+-\$250) per annum at 2000 values. The government has a strategy for the alleviation of poverty through aiming for high rates of economic growth as well as direct welfare payments to poor people. This is unique in Africa as about 11 million poor and vulnerable people, nearly $25 \%$ of the population, receive child support, benefits and pensions. Unemployment is still between $27 \%$ and $40 \%$, and most of these (unemployed) people are from black communities. SA has one of the highest rates of wealth inequality in the world, and there is an increasing level of frustration with the slow rate of progress in overcoming the legacy of apartheid [1].

SA is largely a semi-arid country with a mean annual rainfall of $460 \mathrm{~mm}$ compared to a world average of $860 \mathrm{~mm}$ per annum (the country is among the 30 driest countries in the world). Due to the rainfall pattern, access to water is vital, especially for the agricultural and industrial sectors of the economy. Water is essential for economic growth and all the people of SA should be able to participate in the benefits that can be derived from the access to water. It is the policy of the SA Department of Water Affairs and Forestry (DWAF) that water resources must be protected while development must be promoted. It is essential to maintain the ecological functions on which humans depend, but it is not intended to protect aquatic ecosystems at the expense of all development. The objective is to promote development at levels that are sustainable in the long term [2].

\section{Conservation and sustainable development}

In SA the pressure on resources became critical in the 1980's and 1990s. It became clear that legislation and policies of the past had to be amended in order to provide for the needs of a developing society with due consideration of the environment. In 1994 a new democracy was established in South Africa. The new South African Constitution (1996) guaranteed everyone the right to have the environment protected for the benefit of present and future generations and for it to not be harmful to health or well-being. At the same time it promotes justifiable economic and social development, the right to access to sufficient food and water and the right to dignity. The review of the water law was guided shortly after this through a wide public participation process, culminating in a set of basic principles. These principles were embodied in the White Paper on National Water Policy, 1997 [3], as a statement of Policy and followed up by enacting it in legislation with the National Water Act, 1998 (Act 36 of 1998). Three fundamental objectives for managing South Africa's water resources arise from these principles: 
- To achieve equitable access to water, including access to water services, to the use of water resources, and to the benefits from the use of water resources.

- To achieve sustainable use of water, by making progressive adjustments to water use to achieve a balance between water availability and legitimate water requirements, and by implementing measures to protect water resources.

- To achieve efficient and effective water use for optimum social and economic benefit.

The National Water Act (1998) provides the foundation for water to be managed in South Africa in an integrated manner based on the above principles. The integrated nature and interdependence of water in all its forms within the total water cycle form the basis of management on a catchment or watershed level. A drastic change in the philosophy and practice of water resource management was vital to address the new constitutional obligations and a new approach to the management of water was put in place [2].

\section{Principles and implementation}

The water law reform process developed key principles through a wide public participation process before they were entrenched in the National Water Act (NWA) in 1998 [5].

The water required for basic human needs and the aquatic needs of the environment enjoy priority of use while use of water for all other purposes is subject to authorisation. The degree of utilisation that can be sustained by a natural water resource must be recognised and respected. This depends on maintaining a basic level of ecological integrity and function. The NWA recognises this basic level as the Reserve. The Reserve is intended to protect the resilience of water resources, to satisfy basic human needs by securing a basic water supply and to protect aquatic ecosystems in order to secure ecologically sustainable development and use of the water resource. The ecological Reserve or resource base, i.e. the quantity, quality and reliability of water required to maintain the ecological functions on which humans depend, should be reserved so that the human use of water does not individually or cumulatively compromise the long-term sustainability of aquatic and associated ecosystems. In addition, aquatic ecosystems that are particularly fragile or important can receive additional protection. For this, the NWA provides for ecological categories in assessing the Reserve, a management classification system, and resource quality objectives. The emphasis has shifted away from the traditional primary focus on the development of additional water sources to new approaches which focus on the way water is used and how it can be conserved in each user sector [2].

Water legislation is aimed at making provision for the protection of goods and services that may be used both on and off-site. Rivers are classified and the classification system provides for different desired states (i.e. "natural", "moderately impacted" or "heavily impacted"). Each class represents a 
permissible but different balance between on-site and off-site use of the water resource. This system is a tool to assist resource users in reaching agreement on the range of services that the resource should deliver. Unfortunately there seems to be no common understanding of the Reserve being an ecological means to achieve socio-economic ends [4].

\section{Authorisation of water use}

The authorisation (or licensing) process is used as a controlling mechanism in the management of water resources in South Africa. Ecological, economical and social aspects are the main criteria that influence this process.

The taking of water from a water resource is subject to formal authorisation and certain limits and restrictions are normally imposed.

Section 27 (1) of the National Water Act states that the following factors must be taken into account when issuing authorisations or licences [5]:
(a) existing lawful water uses;
(b) the need to redress the results of past racial and gender discrimination;
(c) efficient and beneficial use of water in the public interest;
(d) the socio-economic impact - (i) of the water use or uses if authorised or (ii) of the failure to authorise the use or uses;
(e) any catchment management strategy applicable to the relevant water resource;
(f) the likely effect of the water use to be authorised on the water resource and on other water users;
(e) the class and the resource quality objectives of the water resource;
(g) investments already made and to be made by the water user in respect of the water use in question;
(h) the strategic importance of the water use to be authorised;
(i) the quality of water in the water resource which may be required for the Reserve and for meeting international obligations; and
(j) the probable duration of any undertaking for which a water use is to be authorised.

When a water use licence application is received, the following factors (in descending order of importance) are normally observed.

- Provision for the Reserve.

- International agreements and obligations.

- Water for strategic purposes (power generation)

- Water for social needs such as poverty eradication, primary domestic needs, and uses that would contribute to maintaining social stability.

- Water for key economic sectors and employment creation. This includes key industries and commerce.

Most water use thereafter can be classified as general economic uses, where allocation should best be dictated by the economic efficiency of water use. Uses of water not measurable in economic terms, which may include convenience uses 
and some private water use for recreational purposes, are likely to be of lowest priority [2].

\section{The licensing process}

The licensing process commences when an applicant approaches the department for a licence to use water. The necessary forms and guidelines are then made available to the applicant.

The applicant is requested to provide information on aspects like the volume of water that is needed, existing water use in the relevant catchment area, the quantity and quality of water available in the catchment, the likely effect on other water users, the impact on the environment, the socio-economic impact on other water users and the redressing of the results of past racial and gender discrimination.

DWAF then determines the Reserve for that catchment, which provides for basic human needs as well as the protection of aquatic ecosystems. With this information it is possible to determine whether any surplus water is available for further allocation.

The Reserve is expressed as a percentage of the mean annual run-off of the catchment where the water will be abstracted. This percentage cannot be allocated as it is reserved for human needs and the environment. The Reserve also stipulates criteria for low-flow conditions, i.e. the flow that must be maintained in the river to support eco-systems in the dry season. In the consideration of licence applications the objective is further to promote beneficial use in the public interest.

\section{Bitou Municipality}

The Bitou Municipality provides water for the greater Plettenberg Bay area, which includes a number of small towns. The main water user is Plettenberg Bay, a rapidly developing coastal resort.

According to annual statistics, there was an average population growth of 3,5\% per annum for the Greater Plettenberg Bay area in the 1996 - 2000 period. (It must be mentioned that official population statistics for this area is not very reliable and the Municipality's own records were used). The growth in water demand between 2003 and 2007 amounts to 6\% per annum, while the annual population growth for the same period was more than $7 \%$. The Municipality estimated that the total population was 61000 persons in 2007 . The projected annual water consumption for 2010 is 4 million $\mathrm{m}^{3}$ and in 2015 approximately 5 million $\mathrm{m}^{3}$. The Bitou Municipality is experiencing serious problems during the peak summer season when the peak week demand rises to more than twice the average annual demand due to the influx of holiday visitors.

The Bitou Municipality applied for the abstraction of an additional 2,17 million cubic metres $\left(\mathrm{Mm}^{3}\right)$ of water per annum, bringing the total to 5,32 $\mathrm{Mm}^{3}$ /annum from the Keurbooms River. The estuary of this river is ecologically sensitive and environmentalists are concerned about the health of this river. 
It is important to remember that under previous water legislation ecological aspects were not always properly considered, and there was a perception that the environment could be neglected.

Although the NWA regards the needs of the environment as a priority, many water users in SA still seem to regard it merely as a stumbling block that must be overcome in order to get a water allocation. Water that flows to the sea is often seen as "wasted" water and a river is sometimes only regarded as a source of water that must be exploited. The benefits of an ecologically healthy river ecosystem are not always appreciated by everybody.

In this case study it was evident that environmentalists and developers could not reach an agreement on the desired state of the river or the estuary. Environmentalists sometimes see rivers and estuaries as pristine ecological assets that must be conserved at all costs. Developers, on the other hand, are normally more interested in the abstraction of water from rivers in order to support development. It is not easy to explain to all parties that rivers must provide goods and services along their entire length (both on and off-site). In many cases DWAF has to decide on a compromise that attempt to satisfy both sides.

\section{The reserve}

A preliminary Reserve determination was done for catchment K60E of which the Keurbooms River forms part.

Total virgin MAR (mean annual run-off) for the catchment is $162,66 \mathrm{Mm}^{3}$.

The Reserve for human needs and the environment is calculated at $33,6 \%$ :

Runoff from Keurbooms $\quad=104,23$ million $\mathrm{m}^{3}$

Less: Existing water use $\quad=2,89{\text { million } \mathrm{m}^{3}}^{3}$

Reserve $\quad=35,02$ million $\mathrm{m}^{3}$

Surplus available in Keurbooms $\quad=66,32$ million $\mathrm{m}^{3}$ per year.

The application was for a total of $8,02 \%$ of the surplus available in the Keurbooms River $(5,10 \%$ of total MAR of K60E)

The preliminary Reserve determination for the quaternary catchment K60E was done. A determination of the Estuarine Ecological Water Requirement (EWR), at a Rapid level, was completed during October 2007. This was undertaken by the Council for Scientific and Industrial Research (CSIR) of SA, with input by supporting estuarine scientists. The catchment hydrology was updated, to provide a range of scenario flows required. It was concluded that the current state of the estuary is a Category A/B (between 'natural' and 'moderately impacted').

\section{Water balance}

The water balance indicates that although there is still water available on an annual basis, there is limited surplus during the dry season. The implication is therefore that water must be abstracted during surplus flow conditions only. This provision was stipulated in the licence conditions. 
It must also be mentioned that the previous water authorisation did not have any limitation on low-flow abstraction and that was a serious shortcoming.

\section{Water conservation and demand management (WCDM)}

The Bitou Municipality has a water demand management programme in place. Water tariffs are designed to encourage water conservation by means of a steep block tariff system with a maximum tariff of R17,71/kilolitre. They have also managed to reduce unaccounted for water from $24 \%$ in $2004 / 2005$ to $18 \%$ in $2005 / 2006$. Severe water restrictions had to be imposed on different occasions.

\section{Objections from interested and affected parties}

Objections were received from various environmental organisations, inter alia the Plettenberg Bay Community Environment Forum, the Plettenberg Bay Water Forum as well as the Wildlife and Environment Society of South Africa (WESSA).

The main objections to this application were the following:

11.1. The confidence of the preliminary (Reserve) determination is low.

11.2. The preliminary determination document has many reservations on the preparation work, e.g. it does not include Reserve Requirements for the associated estuaries etc. An earlier freshwater study for the estuary stated that the system requires $100 \%$ of the present MAR due to the sensitivity of the mouth to closure and the potential change in salinity.

11.3. Uncertainties regarding the adverse impacts of global warming on river flow and the very slow progress of eradication of alien vegetation in the River Catchment.

11.4. The reported flows over the last 8 years will make it difficult to achieve the licensed annual flow applied for. This concern relates to the economics of the time available to exercise the "surplus flow" abstraction, and the capital and operating cost of the large plant and infrastructure involved.

11.5. The rapid residential development and the resultant need to supply water, can lead to a situation where good governance can be abandoned and this can result in unwise abstraction decisions. Eventually the estuary could be at risk.

11.6. Alternative water resource options were not considered.

\section{Response to objections}

The response to the above-mentioned objections is as follows:

11.1 It is not DWAF policy to conduct comprehensive Reserve determinations for ad hoc applications like these and the official policy is that an intermediate Reserve is sufficient for this application. It would be unreasonable to expect that the applicant could wait for a high confidence level of reserve determination to be completed as this can take a few 
years. The cost involved can also not be justified. It must be stressed that a preliminary reserve is normally on the conservative side in favour of the environment.

11.2 An "estuary" Reserve is very expensive and time-consuming and it was not required by DWAF. The applicant, however, appointed a consultant (CSIR) to do a determination of the Estuarine Environmental Water Requirements (EWR), at a Rapid level, and this was completed during October 2007. One of the conditions of the licence is that a programme to monitor the impact of the abstraction on the river and estuary will be introduced. This must be done in collaboration with the (DWAF) regional office. Although the EWR study confirmed that the flow requirements for the estuary were more than that of the requirements for the river, these (estuary) requirements will still be satisfied by the licensing conditions. The study that is quoted actually required that water could only be abstracted after the flood peak occurred ("from the receding limb of the hydrograph of the flood event").

11.3 It is very difficult to quantify the impacts of global warming and this will complicate the evaluation of the licence. It will also be unfair to make the applicant alone responsible for the removal and follow-up operations of alien vegetation on private property. A project to remove the alien vegetation is however encouraged and is currently actively considered by the municipality.

11.4 According to DWAF's interpretation of the flow records, the Bitou Municipality will initially be able to abstract an increased volume of water with the applied conditions. Eventually the infrastructure will have to be adapted to be able to deal with high flow abstraction over short periods. The applicant has already started investigating the possibility of additional storage facilities and it is expected that a new dam will have to be completed by 2012. Bigger pipes and pumps are also planned to accommodate the increased volumes of water.

11.5 The Bitou Municipality has adopted a long-term planning strategy and they have already spent millions of Rands on water resource studies. They have always acted responsibly and it would be unfair to suspect that they will exploit their water resources to their own detriment.

11.6 It is not true that alternative water resource options were not considered. It is mentioned in the consultant's report that groundwater, re-use of sewage effluent, desalination of seawater and removal of alien vegetation were inter alia considered, but these options were either too expensive or there was uncertainty about their sustainability.

\section{Recommendations}

It was recommended that a licence for the abstraction of 5,32 million $\mathrm{m}^{3}$ (an additional 2.17 million $\mathrm{m}^{3}$ ) of water from the Keurbooms River is granted to the Bitou Municipality.

Some of the conditions applicable to this licence are listed here. 
12.1 This licence authorises the taking of a maximum quantity of five million three hundred and twenty thousand cubic metres $\left(\mathrm{m}^{3}\right)$ of water per annum from the Keurbooms River based on an average of fourteen thousand five hundred and seventy five cubic metres $\left(\mathrm{m}^{3}\right)$ per day, for municipal purposes.

12.2 The quantity of water authorised to be taken in terms of this licence may not be exceeded without prior authorisation by the Minister.

12.3 This licence does not imply any guarantee that the said quantities and qualities of water will be available at present or at any time in the future.

12.4 Due to possible over-allocation of water in this water resource, when compulsory licensing is required in future in terms of Chapter 4 of the NWA, this licence shall be subject to a reduction of the allocated volume in order to comply with the requirements of the Act.

12.5 The above-mentioned volume may be reduced when the licence is reviewed.

12.6 The licensee shall continually investigate new and emerging technologies and put into practice water efficient devices or apply technique for the reuse of water containing waste, in an endeavour to conserve water at all times.

12.7 All water taken from the resource shall be measured as follows:

12.7.1 the daily quantity of water taken must be metered or gauged and the total recorded at the last day of each month; and

12.7.2 the licensee shall keep record of all water taken and a copy of the records shall be forwarded to the Regional Director on or before 25 January and 25 July of each year.

12.8 No water taken may be pumped, stored, diverted, or alienated for purposes other than intended in this licence, without written approval by the Minister or his/her delegated nominee.

12.9 The licensee shall only pump water under surplus flow conditions. The pumping of water will only be allowed when the reserve requirements in the Keurbooms River are met at the Department's gauge K6H019.

12.10 The licensee shall put in place a method and/or device that will only allow pumping under such conditions. This method/device and the position of the monitoring point will have to be to the satisfaction of the Regional Director.

\section{Closing remarks}

It was not possible to convince the objectors that the authorisation of additional water for the Bitou Municipality can be justified. In a report that appeared in a local newspaper on 18 November 2008 they stated that this authorisation "could have a disastrous impact on the environment". It must be stressed that a public participation process was followed and that the objectors were informed about all aspects of the licensing process. Special information meetings were convened where all the interested and affected parties had the opportunity to discuss this matter. 
The general reaction was that DWAF applied its mind adequately and that sufficient control measures have been put in place to secure the sustainability of the resource whilst still allowing for economic growth and development.

DWAF is satisfied that a proper process was followed and that it complied with all the legal requirements. The objectors, however, appealed to the Water Tribunal, a statutory body that was established in terms of the NWA.

\section{References}

[1] OneWorld South Africa Guide, http://uk.net/guides/southafrica/development

[2] Department of Water Affairs and Forestry, Fundamental Principles and Objectives for a New Water Law in South Africa, 1997

[3] Department of Water Affairs and Forestry, White Paper on a National Water Policy for South Africa, 1997

[4] van Wyk, E., Breen, C.M., Roux, D.J., Rogers, K.H., Sherwill, T. \& van Wilgen, B.W., The Ecological Reserve: Towards a common understanding for river management in South Africa. Water SA Vol. 32 No. 3 July 2006. pp. $403-409$.

[5] Department of Water Affairs and Forestry, National Water Act, 1998, Act 36 of 1998, Government Gazette, Vol. 398, No 18182, 26 August 1998. 